\title{
On-site Architects' Offices in Major Construction Projects of Budapest in the Second Half of the $19^{\text {th }}$ Century
}

\author{
Kristóf Zoltán Kelecsényi1 ${ }^{*}$, Ágnes Gyetvainé Balogh \\ ${ }^{1}$ Department of History of Architecture and Monument Preservation, Faculty of Architecture, Budapest University of Technology \\ and Economics, H-1111 Budapest, Műegyetem rkp. 3., Hungary \\ * Corresponding author, e-mail: kristof.kelecsenyi@gmail.com
}

Received: 05 October 2018, Accepted: 07 December 2018, Published online: 13 May 2019

\begin{abstract}
During the $19^{\text {th }}$ century, the most renowned architects considered a permanent presence on the site of their larger construction projects necessary. Some of them even maintained several on-site offices close to their construction sites, where architects and designers were contracted for the duration of the construction. This study presents two on-site offices in detail (office of the Palace of Justice and the Parliament Building) while outlining a further four examples in Budapest (office of the Parish Church of Lipótváros, the Ministry of Agriculture, the enlargement of the Royal Palace and the Technical University).

There were three practices used to settle these offices: I. using an older building, before its demolition, near the site; II. in a temporary building set up for this purpose; III. in rented rooms in the surrounding buildings. Examples for the use of existing buildings are the building of the Palace of Justice (A. Hauszmann), the extension of the Royal Palace (A. Hauszmann) and the building of the campus of the Royal Joseph University (A. Hauszmann, Gy. Czigler, S. Pecz). St. Stephen's Basilica (M. Ybl), the Parliament (I. Steindl) and the Krisztinaváros wing of the Royal Palace (M. Ybl, A. Hauszmann) are examples where newly constructed buildings were used, and we assume rented apartments as on-site offices in the case of the Opera House (M. Ybl) and the Museum of Applied Arts (Ödön Lechner). The large public building's on-site offices have great significance in architectural history as well as being theoretical and practical workshops.
\end{abstract}

Keywords

architect's office, architectural practice, Historicism, Royal Hungarian Palace of Justice, Hungarian Parliament Building

\section{Introduction}

In the history of architecture, the name of the leading architect often refers to the architectural praxis; this work organisation strongly showed the process of separation of the professions of architects, master builders and master masons in the second half of the nineteenth century. Additionally, because of the slowness and difficulty of transport and telecommunications, the need for the direct link between planning offices and construction sites had arisen. The most famous architects even maintained several on-site offices close to their construction sites, where architects and designers were contracted for the time of the construction (Gábor, 1996, p. 18; N. N., 1891, p. 76). ${ }^{1}$ As well as these, a central office functioned where smaller design and construction tasks were carried out such as competition plans, authorisation plans of family or tenement houses (Fábián, 1922, p. 94; Hauszmann, 1896, p. 180). ${ }^{2}$ Permanent on-site presence was considered necessary on the site of larger construction projects. In the following, two on-site construction offices will be described in detail (that of the Parliament Building (1884-1902) and the Palace of Justice (1893-1896)). Four further examples will be schematically outlined to analyse the general characteristics and the variance of these buildings and the immediate environment of architectural planning at the end of the $19^{\text {th }}$ century.

\footnotetext{
1 According to the journal Vasárnapi Ujság, "the current staff members of the office, Ybl's previous assistants are temporarily doing the work" at the construction sites after Ybl's death (N. N., 1891, p. 76).
} 


\section{Architect's office of the Palace of Justice - the building of the former Military Wain Warehouse}

Alajos Hauszmann was appointed by the Ministry of Justice in autumn 1891 to build the Palace of Justice (Hauszmann, 1897, p. 57). The building was located in the western part of the site of the former Military Wain Warehouse opposite the Parliament Building, which was under construction. The ministry had already sought to acquire the military-owned site in 1887 as the staging area for the construction of the Parliament Building; ${ }^{3}$ however, new buildings promised in exchange had not been completed, and the military had been unable to move out. Thus, based on the sources, the Imperial and Royal Military Bed and Wain Warehouse was removed from the real estate by the end of April 1893. ${ }^{4}$ Although the site had already been chosen to accommodate the Palace of Justice, it was then maintained by the Execution Committee of the Parliament Building; it is likely that, even before the end of the construction, it was partly used by the same organisation.

The Committee arranged the demolition of the former military buildings, taking into account the planned construction of the Palace of Justice, ${ }^{5}$ with the aim of demolishing all the buildings along the line of the Gorove (today Kozma Ferenc) Street and to the west of it - near to the Parliament - and to keep all buildings to the east side of the site. The area was partly handed over for the construction to Lipót Havel, the groundworks and masonry contractor, in August 1893. ${ }^{6}$ The fully cleared plot was officially transferred to the Ministry of Justice only at the end of October, although the remaining areas were maintained by the construction of the Parliament Building.?

In a letter in August 1893, Havel asked the Executive Committee to rent the two-storey section of the Wain Warehouse at Honvéd Street for Alajos Hauszmann's design and foreman architect's office for two hundred

3 Országgyülés Hivatala; Országházépítés: Végrehajtó bizottsági ülések jegyzőkönyvei (Office of the National Assembly; Construction of the Parliament building: Protocols of the sessions of the Executive Committee, hereafter: OH: VB-JK) - XXII. session (28. 11. 1887.), X. 4 OH: VB-JK - XLVIII. session (04. 07. 1893.), VI.

5 Országgyülés Hivatala; Országházépítés: Eredeti szerződések (Office of the National Assembly; Construction of the Parliament building: original contracts, hereafter: OH: SZ-E) 45. (12. 07.1893.) Contract of Sommer, Ignác.

6 Országgyűlés Hivatala; Országházépítés: Végrehajtó bizottság iratai (Office of the National Assembly; Construction of the Parliament building: Documents of the Executive Committee, hereafter: $\mathrm{OH}$ : VB) $374 / 1893$.

7 OH: VB 435/1893.
Forints per year during the construction of the Palace of Justice $^{8}$ According to his contract, the contractor was obliged to maintain the office of the foremanship:

"The contractor of the masonry is bound to build a heatable and lockable office for the construction management [the foreman and the construction inspector] and its staff at his own expense, to heat and keep it in order, and to provide it with a servant. If an office building cannot be established on site due to lack of space, he is bound in this case to rent a bright and healthy apartment in one of the tenement houses in the neighbourhood at his own expense." 9

After the demolition, the buildings left along the boundaries of the plot included one-room, two-aisled warehouses, leaving the middle part of the Honvéd Street wing as the only exception, a one-storey high part of a building formerly serving as the management centre of the warehouse and as an officer's residential house (Fig. 1). According to the foundation-stone sought out during the demolition, the former buildings of the warehouse were built in $1816,{ }^{10}$ but the two-storey section, which was found suitable for the architect's office, was built only between 1838 and 1854 according to the contemporary cadastral maps.

According to the documents produced during the rental, the building was in good condition. After Imre Steindl, designer of the Parliament building, resigned the use of the building, in his statement, the Executive Committee did not see any obstacles to its renting, but they found the rent offered by Havel low for a building with fifteen rooms in good condition with two floors (Fig. 2). They wanted double the amount, and to conclude the contract with a quarterly cancellation term because the southern parts of the former military building extended beyond the line of the recently modified plans for Alkotmány Street, which they, on all accounts wanted to release for the millennium celebrations. According to the contract, finally signed in November 1893 , the building was rented for 500 Forints per year as the architect's office of the Palace of Justice until $1^{\text {st }}$ May $1895 .{ }^{11}$

Thus, the elaboration of the detailed plans of the Palace of Justice was conducted by Alajos Hauszmann

8 OH: VB 321/1893.

9 Budapest Főváros Levéltára (Budapest City Archives, hereafter: BFL) XI.814. Documents of Havel, Lipót, master builder, 58. box.

10 OH: VB 334/1893

11 OH: VB 476/1893; OH: SZ-E 55. (16. 11. 1893.) 


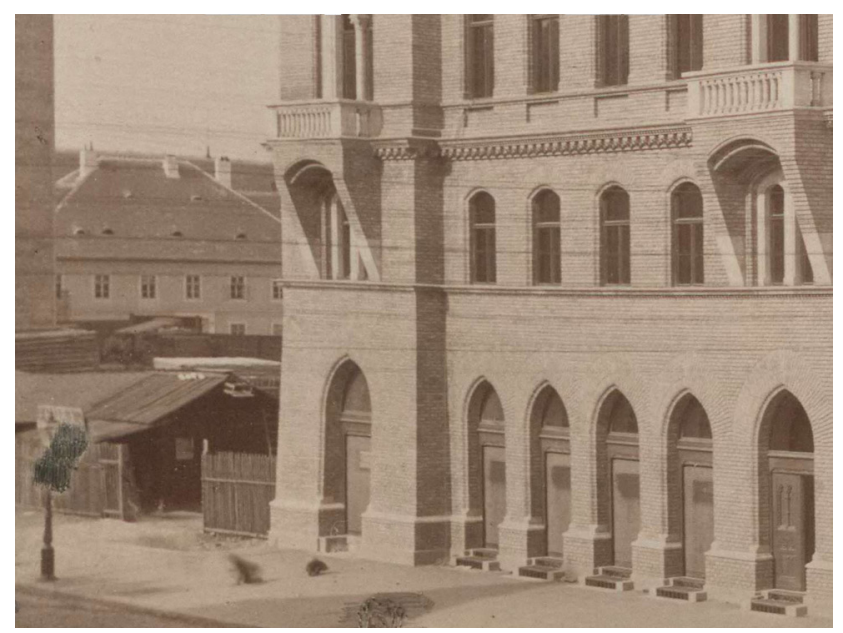

Fig. 1 View of the on-site office of the Justice Palace behind the Unitarian Church and Tenement House in Alkotmány Street, after 1890

(Source: National Archives of Hungary, T6 No. 8/13. - detail)

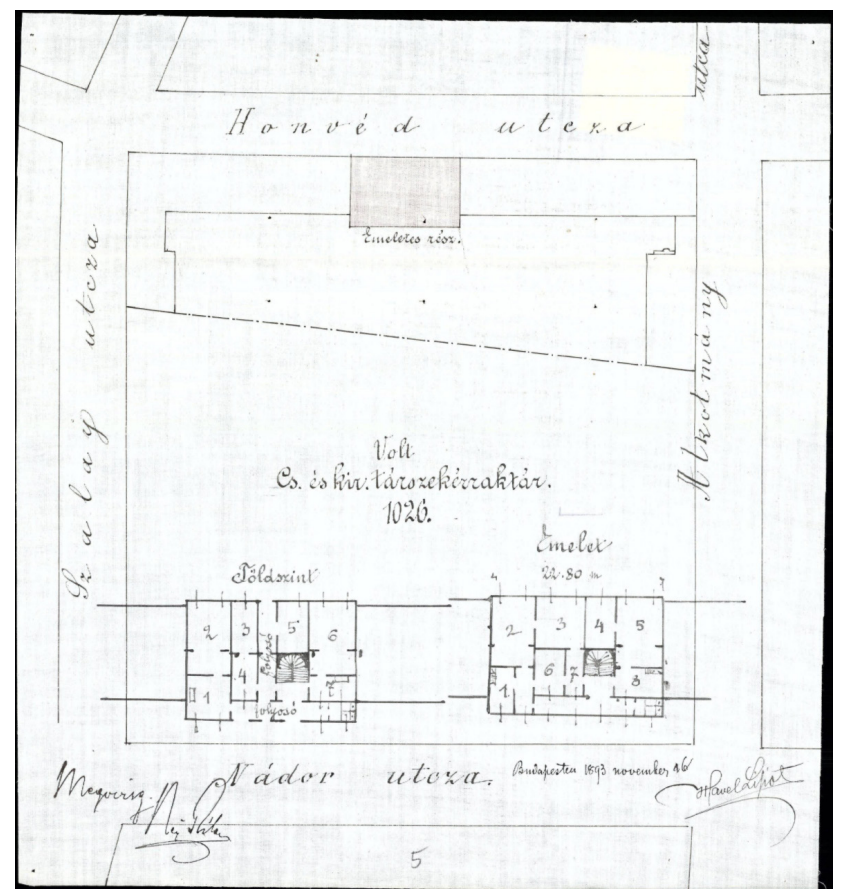

Fig. 2 The situation plan and floor plans of the multi-storey part of the former Military Wain Warehouse, 1893

(Source: Plan Collection and Archives of the Department of Engineering, Office of the National Assembly: SZ-E-55, Contract with Lipót Havel, 1893. 11. 16., attached plans)

in an earlier administrative and residential building. The U-shaped staircase between the ground and the first floor was joined from the south to a gateway, which opened from Honvéd Street in the middle axis. Two bigger and two smaller rooms were on the street side behind the seven-axis façade, and on the courtyard side, a semi-open corridor was situated with lavatory at the south end. The first floor had a similar layout, with the difference that the three rooms on the street side were bigger. Probably there was some remodelling, but related documents are missing.

At this time, Hauszmann's head office was led by Flóris Korb (1860-1930), who was also involved in the designing of the Palace (Hauszmann, 1897, p. 67). Korb had been employed by Hauszmann since the beginning of the 1880 s, which post he got on the recommendation of Ignác Alpár (1855-1928) (Hauszmann, 1997, p. 57; Komor, 1930, p. 217). In his article about the New York Palace published in autumn 1892, Hauszmann publicly supported the setting up of the independent office of Korb and Kálmán Giergl (1863-1954), who was also employed by him:

"Presenting the plans of the New York Palace, I take the opportunity to introduce to my colleagues my former students and for years zealous associates, Flóris Korb and Kálmán Giergl, architects, who worked with me on this building as intellectual co-operators. They have been involved in many of my constructions and have shared the burdens and worries of my work, and I'm only doing my dearest duty if I share with them my enterprises and I support these excellent young architects to occupy the position they deserve in the practice of our profession." (Hauszmann, 1892b, p. 325) ${ }^{12}$

Hauszmann's intention to help soon resulted in a commission, which became the architects' first independently designed building: the house of the Pesti Hírlap (Pest News) (Komor, 1930, p. 218). ${ }^{13}$ Without this, we could consider Korb's following recollection as fondness towards his master:

"... if anybody asks me, (...) why came most of them from his office who are taking their places still today among the choicest colleagues, and why not for example from the also excelling Miklós Ybl's or Imre Steindl's side, the answer for this question is not difficult: this is because Hauszmann did not consider who worked with him as drawers or lads (...), but colleagues in the noblest sense of the word, always with the benevolent leadership of the master, within

12 Special thanks for Márton Székely for drawing our attention to the detail quoted.

13 Today: Budapest, V. Bajcsy-Zsilinszky Street 78. He writes about "warm support" of Hauszmann on the occasion of obtaining the commission. 
the framework of the necessary discipline, he could work freely ..." (Hauszmann, 1995, p. 48) 14 $^{14}$

It is quite possible that the same spirit was detectable in the on-site office of the Palace of Justice, where the entrusted leader was János Zuschmann (1856/57-1915) (N. N., 1915, p. 188) after the separation of Korb around 1893-1894. ${ }^{15}$ Zuschmann was "inherited" by Hauszmann as one of the leaders of the on-site office of the Royal Palace in Buda after the death of Miklós Ybl (1814-1891) (Hauszmann, 1997, p. 82).

Several members of the young architect-generation were also employed in the on-site architect's office of the Palace of Justice. Their names can be observed as witnesses in the contracts concluded during the construction: Géza Aladár Kármán (1871-1939) (Pálinkás, 2015), ${ }^{16}$ Albert Körössy (1869-1955) (Baldavári, 2015), ${ }^{17}$ Marcell Komor (1868-1944), ${ }^{18}$ furthermore Miklós Huber ${ }^{19}$ and József Szentpály (both master builders) were members of the office. ${ }^{20}$ The rental contract of the on-site office building in Honvéd Street expired in May 1895, but it could certainly have been used until the middle of the summer, as the abandonment of the building took place only at the beginning of August. ${ }^{21}$ Subsequently, the office was likely to have been moved to a secure part of the Palace, still under construction.

\section{Architect's office of the Parliament - a newly built, temporary on-site office}

Imre Steindl won the commission for the new permanent Parliament building on the bank of the Danube in Lipótváros following an architectural competition

14 The memoir of Flóris Korb is quoted in Alajos Hauszmann's autobiography.

15 Little data is available about János Zuschmann. His obituary appeared in the Magyar Mérnök- és Építész-Egylet Közlönye in 1915. 16 Országos Bírósági Hivatal (National Judicial Bureau, hereafter: $\mathrm{OBH})$ - Construction of the Palace of Justice - contracts 46. Paolo Triscornia di Ferdinando (27. October 1894.)

17 First appearance of his signature was on Lipót Havel's contract in summer 1893 as a witness. BFL XI.814. Documents of Havel, Lipót, master builder, 58. box.

$18 \mathrm{OBH}$, contracts, 47. Strobl, Alajos (27. October 1894.)

$19 \mathrm{OBH}$ Construction of the Palace of Justice - contracts 34. Magaziner and Weinberger (2. March 1896.)

$20 \mathrm{OBH}$ Construction of the Palace of Justice - contracts 44. Róna, József (23. January 1894.)

21 OH: VB 1895-464.
(Gábor, 2000, p. 164). The contract was signed on $5^{\text {th }}$ March 1885 , according to which the staff and the required equipment of the on-site office had to be paid by the designer's honorarium (Zámborszky, 1937, pp. 35-40). ${ }^{22}$ The contract did not impose anything about the building of the office, as it had been under preparation for a long while.

Although a few suitable buildings stood in the direct vicinity of the future Parliament building at this time-such as the formerly discussed military warehouse or the Ship Bureau - none of them had been used. The problem was solved with a brand new two-story on-site office building. Playing a great role in this decision, was the fact that the building had to include the meeting room and presidential office of the construction supervising board, the Executive Committee. The plans of the on-site office were signed by Imre Steindl on $12^{\text {th }}$ July 1884 , and it was authorised four weeks later. ${ }^{23}$ The plan shows a freestanding, oblong building with an east-west longitudinal axis, located north-west from the corner of Géza (now Garibaldi) and Akadémia Streets (Fig. 3). The jerkinhead roofed building with its plain façade, was built as close as possible to the existing parts of Lipótváros and the Danube quay (Fig. 4).

According to the authorisation plan, the building could be accessed from the middle of the southern side. The levels were accessible through a three-armed staircase opening directly from the courtyard entrance. A part of the ground floor and the second floor served for the planners, while the first floor was meant to be the home of the Executive Committee and the technical inspectorate. On the ground floor, a large, six-windowed room was used as "drawing-room for nature-sized plans", and other rooms were dedicated to the janitor and to a tool chamber. The northern part of the first floor was almost fully occupied by a large drawing room with seven windows and was filled with three smaller offices and a "teacher room" - probably the office of the leading designer. There were also lavatories near the stairs at each level (Fig. 5).

Following the authorisation, an auctioned tendering was held on $1^{\text {st }}$ September $1884 .{ }^{24}$ Fifteen entrepreneurs purchased the documentation - including major contractors such as Josef Amon, Lipót Havel, Napoleon Kéler, János

$22 \mathrm{OH}$ : VB 1884-45; the final text of the contract has been preserved in copy. 23 BFL XV.17.d.329 hrsz.: 24894, 2. folio - 40330/1884-III. (1884. 08. 08.)

24 OH: VB 1884-7. 


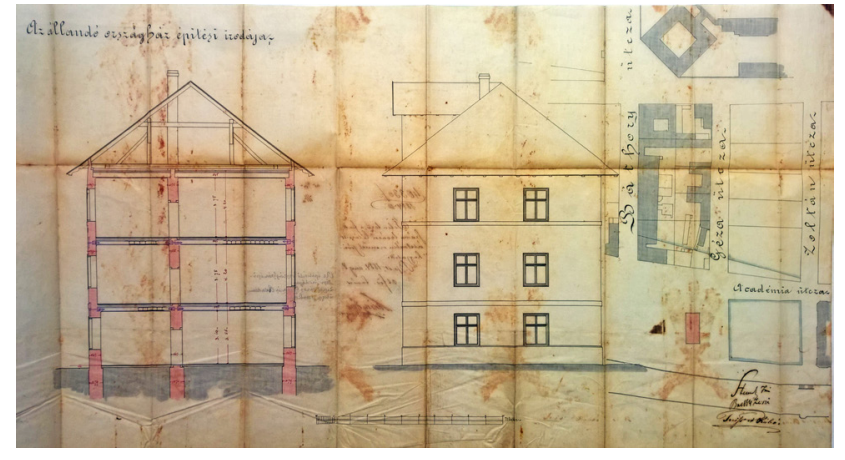

Fig. 3 The situation plan and façades on the authorisation plan of the on-site office of the Parliament, 1884

(Source: Budapest City Archives - XV.17.d.329, 24894 / 2. f.)

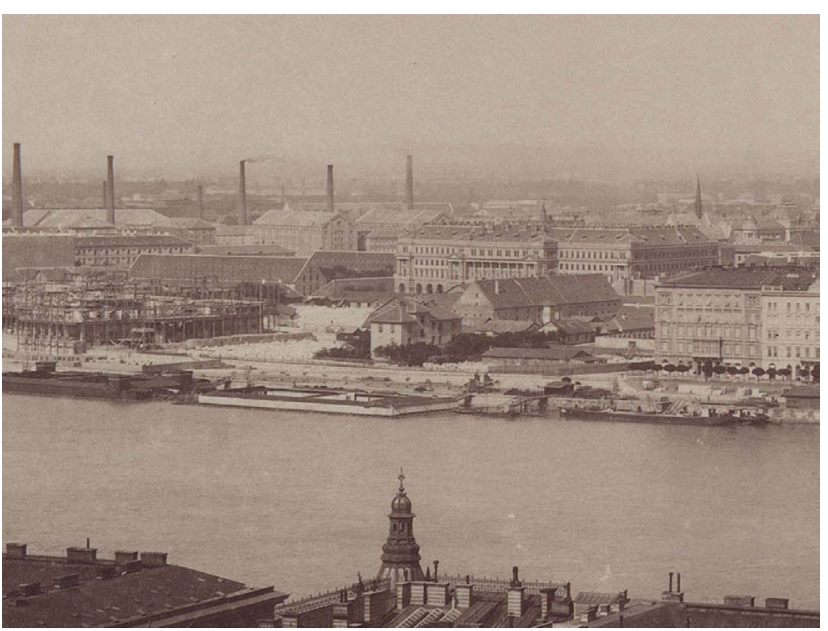

Fig. 4 The on-site office (in the centre) near the Parliament in the course of construction on the Danube bank, around 1892 (Source: Budapest City Archives. XV.19.d.1.07.195)

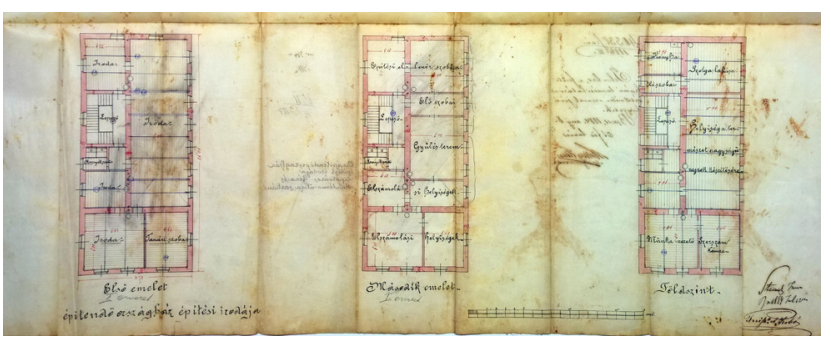

Fig. 5 The layouts on the authorisation plan of the on-site office of the Parliament, 1884

(Source: Budapest City Archives - XV.17.d.329, 24894 / 1. f.)

Kauser and József Pucher - although only ten tenders were submitted. ${ }^{25}$ Such a small construction task would not have attracted a large number of members of the construction industry in general terms, but the opportunity to appear at the construction of the Parliament building made it

25 OH: VB 1884-12.
attractive.The Preisz and Szabó Company's lowest bid of 24,114 Forints was selected. In addition to other details, the announcement also stipulated that the building should be roofed before the winter and must be completely ready by the $1^{\text {st }}$ May 1885 . The contract was signed with a tight eightmonth deadline on the $3^{\text {rd }}$ September, with some technical modifications of a few points compared with the announcement. ${ }^{26}$ The most significant change was due to fire safety considerations. Instead of the originally planned wooden stairs, a stone stepped staircase was ordered, which slightly increased the costs of construction. ${ }^{27}$

The detailed budget shows a number of technical details, and it is also clear that the building was designed to last for more than just a few years. ${ }^{28}$ The base had to be constructed like a brick wall with limestone lines, to which brick walls were to be built. The flooring of certain rooms was designed with brickwork, the ceilings and the walls were plastered and painted. The staircase was planned with iron railings, on the ground floor and the landings with a single coloured terrazzo covering. The latter was also used in the lavatories. In order to heat the building, four to six iron stoves were purchased per floor. They also provided for a constant light source; the building was designed with gas illumination, which was provided by four, two or single armed chandeliers and wall-lamps. The large drawing room was also equipped with mechanical ventilation.

The construction started at the beginning of autumn on $25^{\text {th }}$ October. At that time, 18 stonemasons, two apprentices, five scaffolders, 13 male and 18 female day-labourers worked on the building. ${ }^{29}$ In spring 1885, the furniture was ordered from Alajos Michl's joinery, from János Herold's tapestry factory, and for the rooms of the Executive Committee on the $1^{\text {st }}$ floor, from the Thonet Company in Vienna. ${ }^{30}$ Among other things, large storage cabinets were ordered with roller drawers for plans, a 3.5meter long and 1.3-meter wide table and eight spittoons for serving the meetings of the Committee. It refers to the state of public safety in the area, in that it was necessary to build a "permanent police station", for the security of the plans and equipment stored in the office and to the staff staying there late in the evening. ${ }^{31}$ The con-

26 OH: VB 1884-11.

27 OH: Építészeti Tanácsülési jegyzőkönyvek (Protocols of the Architectural Council's meetings - I. session (11. 10.1884.), I/H. 28 OH: VB 1884-11.

29 OH: VB 1884-37.

30 OH: VB, 1885-36 (Michl and Herold), OH: VB, 1885-56 (Thonett). 31 OH: VB 1885-29. 
tract for painting the office was signed at the end of April with Róbert Scholtz, room and decorator painter. ${ }^{32}$ During May arrangements were made for the gas, in addition to the already functioning water pipe. ${ }^{33}$ In mid-June, regularising the surroundings of the building was authorised, which implied largely filling-works and included a six-meter-wide paved carriageway and a 2-meter wide pathway to the entrance of the building from Akadémia Street; the plot was also fenced in. ${ }^{34}$

The building was put into use, with a slight delay, on $9^{\text {th }}$ July $1885 .{ }^{35}$ It was in this month that the telegraph was connected, ${ }^{36}$ and at the beginning of autumn, the soil-covered parts of the plot were landscaped, including the planting of as many as 500 bushes and 100 trees. $^{37}$

The plans showing the final state of the building have survived. ${ }^{38}$ Only minor changes can be observed compared to the authorisation phase: some of the dividing walls were built elsewhere, and the drawing room on the ground floor gained an additional ante-room. We can get a glimpse of the design office on the second floor from a photo taken in 1896 (Fig. 6). According to the contract, Imre Steindl had to provide the equipment for the office; thus they are not included in the annual inventories. On the photo, we can observe the gas lamps on the ceiling, the free standing oil lamps, a few plans, drawing tools, pattern books, granite and plaster samples, the built-in ventilation hatch, the Scholtz-company's rolled patterned walls and the decorative ceiling as well as a Madonna portrayal.

There are a few recollections about the on-site office, one of them, a memoir of Gyula Sándy is not only about the working conditions, but also about the everyday activities of the office:

"In the huge office, 15 of us worked then [in the summer of 1890], the official hours were from 8 in the morning to 12 and from 2 to 5 in the afternoon. (...)" (Sándy, 2005, p. 16)

"In the course of my work, the planning competition for the parish church of Erzsébetváros on Rózsák Square (then Szegényház tér) was announced, with a

32 OH: VB 1885-49.

33 OH: VB 1885-73.

34 BFL XV.17.d.329 hrsz.: 24894, 3. folio - 29664/1885-III

(17. 06. 1885.); OH: VB $1885-58$.

35 OH: VB 1885-69; OH: VB 1885-126. 29792/1885-III. (09. 07. 1885.)

36 OH: VB 1885-123.

37 OH: VB 1885-204.

38 OH: VB 33/1887. enclosed drawings.

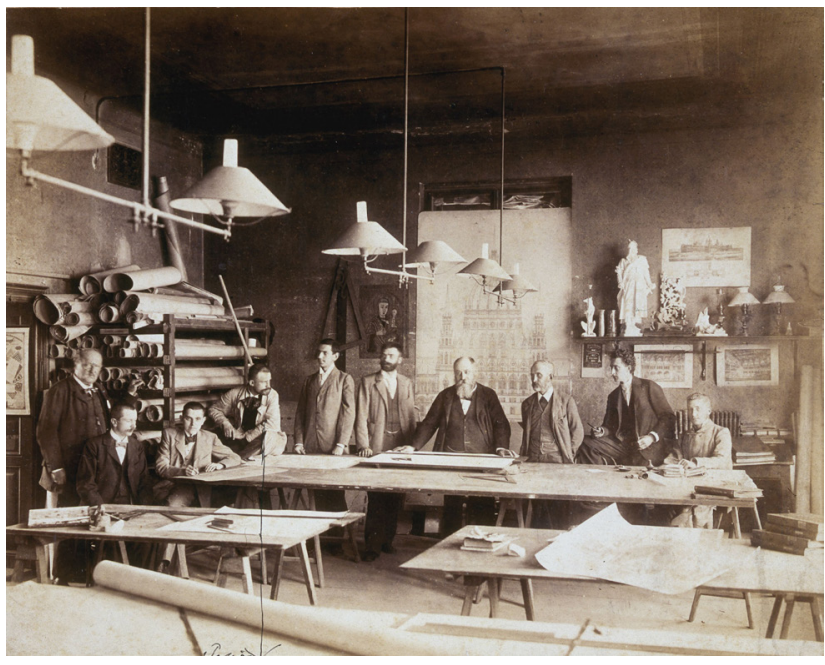

Fig. 6 Imre Steindl among the employed architects in the on-site office, photo of Károly Divald, Jr., 1896

(Source: MÉM-MDK, without inv. no.)

deadline on the $20^{\text {th }}$ of August. Steindl was ambitioned to build a church in Budapest despite his task to construct the beautiful Parliament. So, he set half of his huge office for two weeks - including me - to help him participate in the competition." (Sándy, 2005, p. 151)

Ottó Tandor (1852-1913) was entrusted with the task to lead the on-site office until 1896, and from autumn 1895, he also directed the construction of the parish church of Erzsébetváros, which was also designed by Steindl (N. N., 1895, pp. 2-3). After the façades of the Parliament were completed, István Santhó (1858/59-1908) took Tandor's place..$^{39}$ During the 18 years of the construction, at least two dozen architects appeared in the on-site office. (More about the staff and the effect of the office: Gyetvainé Balogh and Kelecsényi (2018) and Sisa (2004)). Among others, Ernő Foerk (1868-1934) (Hadik, 1984), Ottó Sztehlo (1851-1923), Ferenc Schömer (1859-1925) (Bede-Fazekas, 2016), Gyula Schweiger (1846-1930) (Havas, 2017) and Ede Toroczkai Wigand (1869-1945) (Keserü, 2007) worked on the plans of the new Parliament building.

The office building fell into a poor condition by the end of the 1890s. It was necessary to repair the emerging cracks on the building, which stood on the freshly infilled ground, without a cellar. However, instead of strengthening, it was decided to move the office and to demolish the building, which would have happened anyway in the next

39 OH: VB-JK LXVI. session (22. 10.1896.), IV.; LXXI. session (02. 07. 1897.), XIII. 
two or three years because of the projected landscaping. ${ }^{40}$ The office moved to the mezzanine of the eastern wing of the Parliament, to the gatekeeper's former apartment, and the demolition of the vacant on-site office building took place in May $1900 .^{41}$

\section{Other on-site offices}

When Miklós Ybl took over the management of the stalling construction of the parish church of Lipótváros (later called St. Stephen's Basilica) in 1869, a bazaar was erected to collect money to help the construction (Fig. 7) (Kemény, 2010, pp. 123-124). The on-site office for the architects was developed in 1873, as single storey, narrow depth building, which framed the construction site from the south, west and north (Kemény, 2010, p. 125). ${ }^{42}$ It was built in connection with the inner side of the southern wing of the building, at Váci Boulevard (now Bajcsy-Zsilinszky út). ${ }^{43}$ The on-site office and the related workshops and warehouses stood in the way of the construction of the terrace around the church in the early 1890 s, so they were transformed around 1893 (Fig. 8). It was decided that, in the following year, because of the millennial celebrations in 1896, the bazaar and the connecting structures had to be demolished (Kemény, 2010, p. 149); although, the building committee managed to keep the northern wing, where the on-site office was relocated in 1895 (Kemény, 2010, p. 151). This building was dismantled in July 1905, shortly before the consecration of the St. Stephen's Basilica, resulting in a separation of the office staff (Kemény, 2010, p. 178). Compared with another notable construction work, there are only a few facts known about the staff of this office: Ybl "inherited" the foreman Henrik Voigt from József Hild, Voigt was replaced by Ferenc Jakabffy in 1879 for one year, and Ferenc Sturm was his successor until the completion of the construction (L-r., 1905, p. 392).

In summer 1885, the on-site office building was erected as a timber construction on the corner of Alkotmány and Nádor Streets (part of Kossuth Lajos square today) (Gyetvainé Balogh et al., 2018, p. 37; Kelecsényi and Gyetvainé Balogh, 2019). Unfortunately, the details of the building are not known due to the lack of plans or

40 OH: VB 1898-461.

41 OH: VB 345-1900; 394-1900.

42 BFL XV.17.b.312 (Építő Bizottmány tervei - Plans of the Building

Commission), 919/1873.

43 The rooms can be observed on an engineering plan of 1892

linked to the construction of a terrace around the building.

(BFL XV.17.f.331.b 150-24/1.)

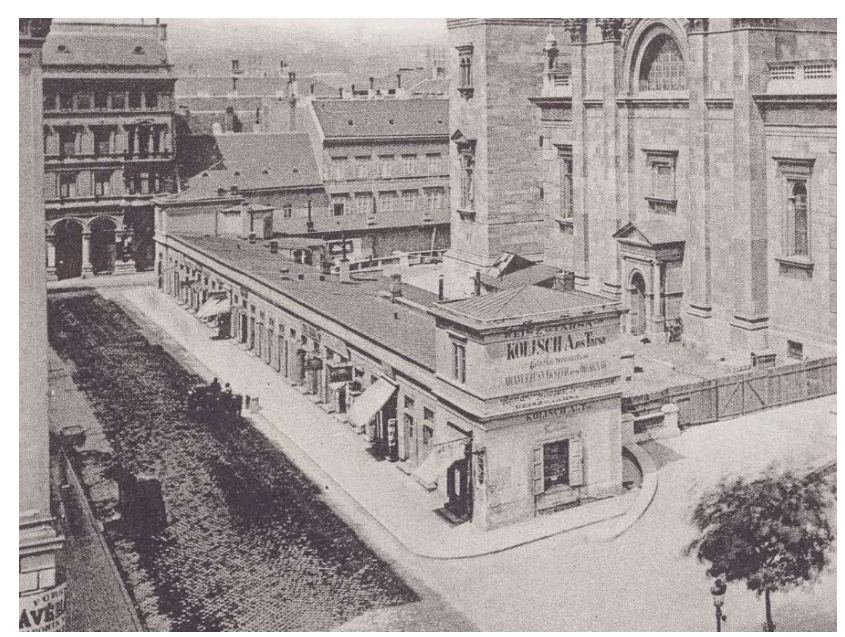

Fig. 7 The southern wing of the strip-mall around St. Stephen's Basilica, whose inner side is joined by the on-site office, before 1896 (Source: FSZEK 020595)

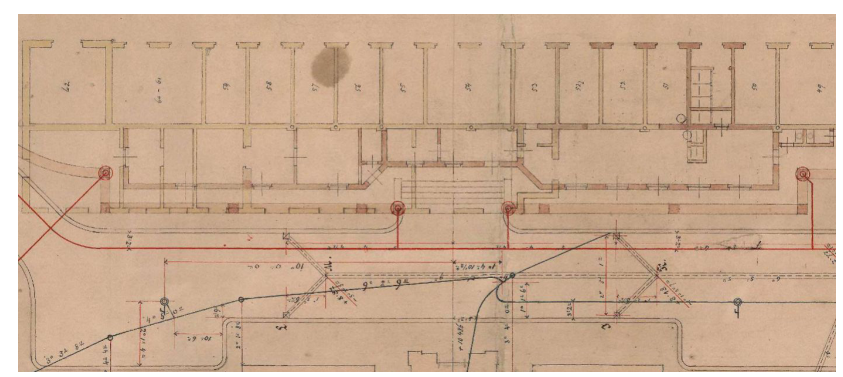

Fig. 8 Plan for the podium-terrace of St. Stephen Basilica, which also shows the transformation of the on-site office, around 1893

(Source: Budapest City Archives XV.17.f.331.b 150-24/1, detail)

photographs about it. In addition to the leading designer, the building office consisted of two architect-builders: Gyula Illés and Vilmos Grundmann. ${ }^{44}$

After Ybl's death in 1891, Alajos Hauszmann took over the planning of the Krisztinaváros-wing of the Royal Palace. The on-site office was then housed in one of the buildings of Attila Street, which runs under the Castle Hill. Because the building blocked the way of a projected road to the Castle, it was decided that it be demolished. The new office was located next to this newly-paved road, in a representative-looking villa-house, which was also intended to be a model for developing the area (Fig. 9). The building was planned to be used for only six to eight years by architects and then relocated to the premises of the Royal Palace that was yet to be built. The costs of the building (24,000 Forints) were paid by the contractor Antal Holzspach and Sons;

44 MNL OL - Magyar Nemzeti Levéltár Országos Levéltára, (National Archives of Hungary) K-178. 1120 f. 309-310. (767/1888/eln.) 


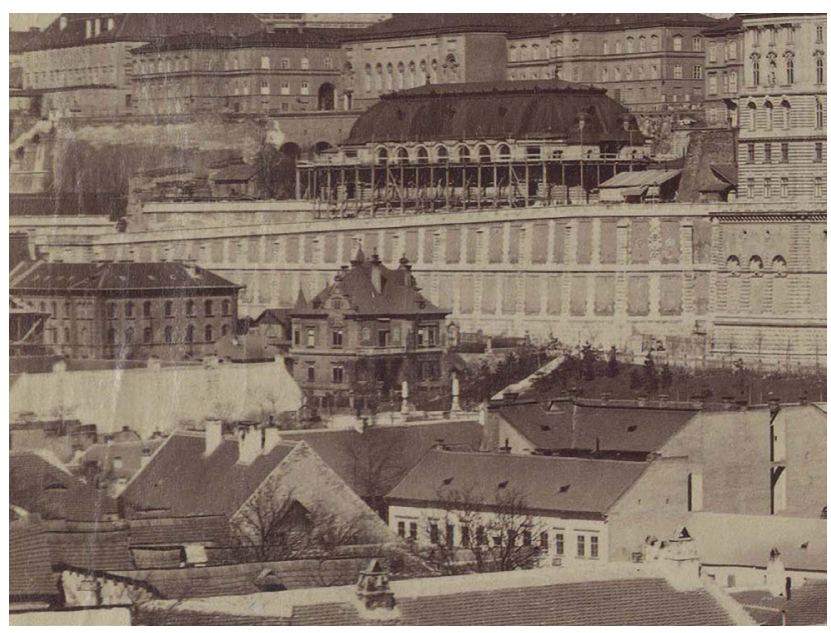

Fig. 9 The lead architect's "villa" under the Buda Castle, in the background, the Riding-hall under construction, and the freshly built Krisztinaváros wing of the Royal Palace, photo of György Klösz, around 1899

(Source: Budapest City Archives XV.19.d.1.08.093)

it may have been owned by the firm after being vacated by the architect's office. Hauszmann produced the plans and the construction began in summer 1891 and lasted until the following May (Hauszmann, 1892a, p. 135).

The three-storey building stood on sloping ground, with the entrance opening from the new road to the Castle and leading to the "upper ground-floor" (Hauszmann, 1892a, p. 134). All the single rooms opened from a common ante-room: the east-south looking corner room of the leading architect, the large west-facing drawing room with a bathroom and a lavatory and a south-west facing terrace. The "lower groundfloor" (Hauszmann, 1892a, p. 149) had almost the same layout, the writing room was under the lead architect's office, and another drawing room was located under the other one. On the smaller scaled first floor (Hauszmann, 1892a, p. 157), a single living room with a closet and bathroom were placed, presumably a flat for the housekeeper (Fig. 10).

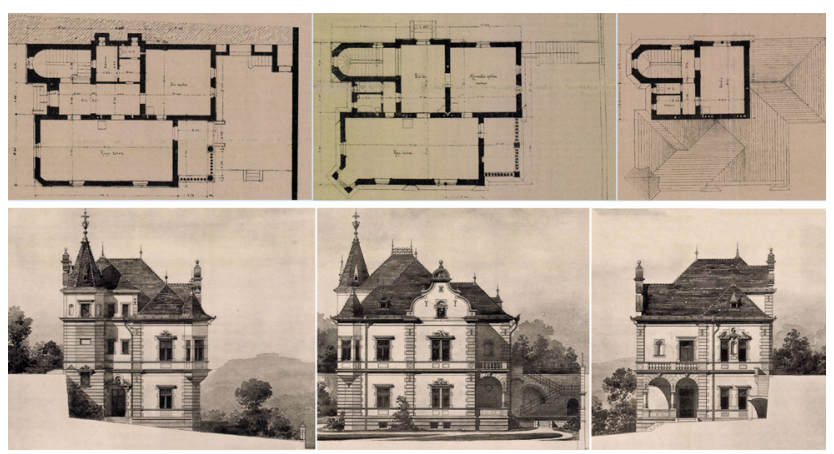

Fig. 10 Floor plans of the lead architect's "villa", 1892 (Source: Hauszmann, 1892a)
When the construction of the northern expansion of the palace began, the Zeughaus building on Szent György Square was partly occupied by the on-site office, which was no doubt much closer to the planned northern parts of the royal residence. The use of this military depository building had already been proposed by Miklós Ybl in the 1880 s, but the military did not sell it at that time. Even so, the Castle Building Committee's office was set up here, and Ybl's expansion plans, completed in 1885, were also exhibited in the building (Bánrévy, 1933, p. 136). The site was taken over from the army at the end of 1897, and its demolition started almost immediately as it occupied the plot of the planned wing of the Royal residence. However, the wings of the management office were dismantled only in 1899 , when the on-site offices were rehoused, presumably within the palace (Fig. 11) (Bánrévy, 1933, p. 137).

Géza Györgyi (1851-1934) and János Zuschmann started working on the expansion of the palace as employees of Ybl. The latter's role in the construction of the Palace of Justice between 1893 and 1896 has been mentioned. Györgyi was a general deputy of Hauszmann. After 1896, Zuschmann was assigned to design the northern extension at Hauszmann's office, Dezső Hültl (1870-1946) the wing of Krisztinaváros, Károly Habicht (1864-1913) the Riding-hall, or only its structures according to other sources, and Guido Hoepfner (1868-1945) the other buildings of the palace complex (Rostás, 2001, p. 523; Sárosi, 1902, p. 7). ${ }^{45}$ It cannot be ruled out that this meant operating in separate offices.

The construction of the South Buda campus of the Royal Joseph Technical University (today Budapest University of Technology and Economics) started in spring 1903, in the area south of Szent Gellért Square according to the plans of Győző Czigler, Alajos Hauszmann and Samu Pecz. Along the Promontori road (today Budafoki Street) Kohn's distillery occupied the plot of today's library, to a greater part. The buildings of the former factory served as depositories during the construction of the university and were gradually demolished. The architectural master builder, Lipót Havel (1847-1933), signed the authorisation plan for the on-site office, which shows the transformation of a part of the distillery for this purpose. ${ }^{46}$ The existing

45 The contemporary article and the contemporary documents published by Rostás contradict each other the about exact role of the members of the office.

46 BFL XV.17d.329. Építési Ügyosztályok Tervtára (Plan Collection of the Building Departments). 5534. The temporary office building of the construction of the Royal Joseph Technical University, 10. August 1906. 


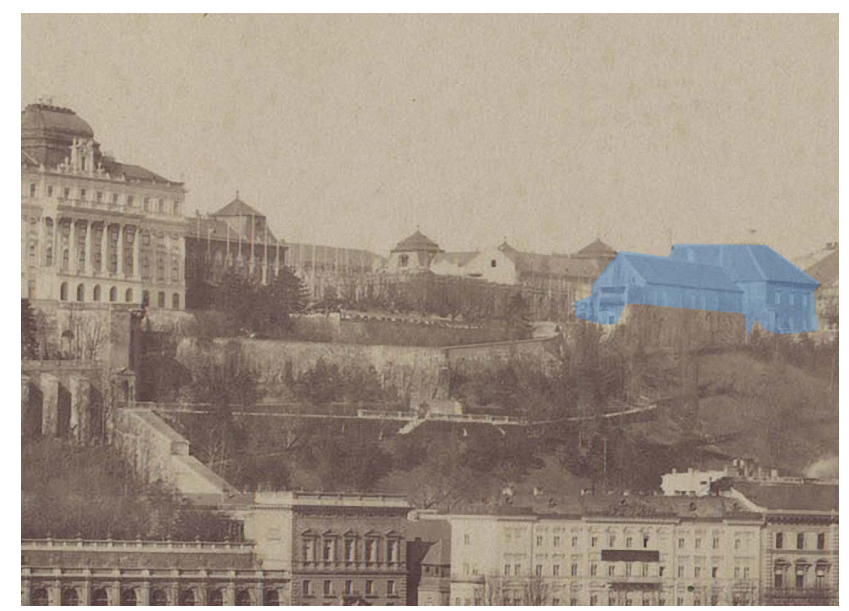

Fig. 11 The maintained wing of the Zeughaus for the on-site office of the northern wing construction of the Royal Palace (marked with blue), photo of György Klösz, around 1899

(Source: Budapest City Archives XV.19.d.1.08.092)

L-shaped building gained a staircase extension at the inner corner of the wings. By moving some of the dividing walls, four offices, a three-roomed service flat, two lavatories, a bunker and a "chamber of tools" accessible from the outside came into existence. On the newly built first floor, there were three large drawing rooms, three office rooms, one closet and two lavatories (Fig. 12). This building can be easily seen in the background of a contemporary photograph behind the library building during the construction (Fig. 13). According to the central building's construction diary, the demolition of the office started on $15^{\text {th }}$ May 1909 when the construction of the university was finished. ${ }^{47}$ As far as we know, the architects Géza Györgyi, János Zuschmann, János Adorján, László Szombathy and Béla Zerkovits worked in the on-site office.

\section{Conclusion}

The known on-site offices were always placed in the direct surroundings of the construction, to enable an overview of the site. Based on these examples, there were three practices to settle these offices:

1. using an older building before its demolition near the site;

2. in a temporary building set up for this purpose;

3 . in rented rooms in the surrounding buildings.

Examples for the use of existing buildings are the building of the Palace of Justice (A. Hauszmann), the extension of the Royal Palace (A. Hauszmann) and the building of the

47 BMEL, Diary about the construction of the K building 1906-1909.

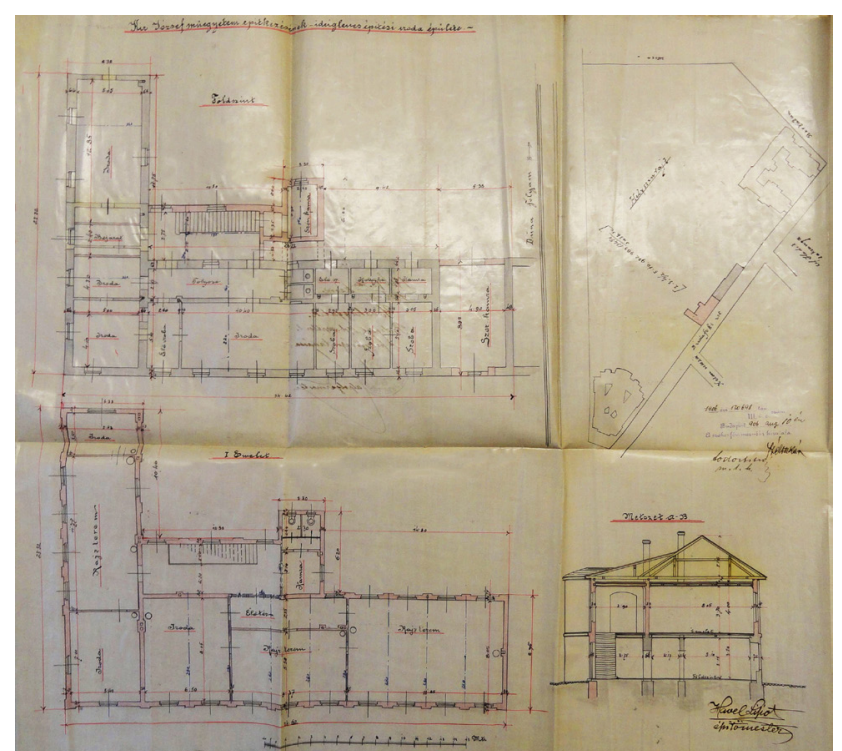

Fig. 12 Authorisation plan for conversion of Kohn's distillery into an on-site office, 1906

(Source: Budapest City Archives XV.17.d.329, 5534)

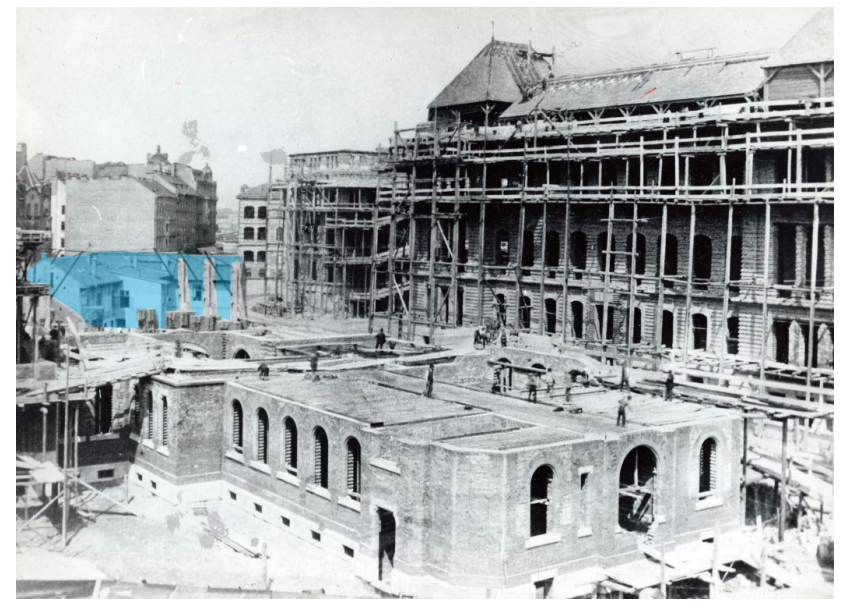

Fig. 13 The on-site office of the University construction in the background (marked with blue), and the erection of the library building in the foreground, around 1907

(Source: after Gy. Balogh, 2013. p. 48.)

campus of the Royal Joseph University (A. Hauszmann, Gy. Czigler, S. Pecz); for the newly erected buildings, the St. Stephen's Basilica (M. Ybl), the Parliament (I. Steindl) and the Krisztinaváros wing of the Royal Palace (M. Ybl, A. Hauszmann). We presume rented apartments as on-site offices near the construction of the Opera House (M. Ybl) and the Museum of Applied Arts (Ödön Lechner).

The large public building's on-site offices have great significance in architectural history as well as being theoretical and practical workshops. The most talented disciples were entrusted with leading the construction of a building after their university training, and it seems almost 
compulsory for their successful career and to become independent later. The systematic research of these, as well as other offices, may further enrich our knowledge

\section{References}

Baldavári, E. (2015) "Kőrössy Albert Kálmán (1869-1955): A szecessziók mestere" (Albert Kálmán Körössy (1869-1955): Master of the Secession), In: Rozsnyai, J. (ed.) Építőmüvészek Ybl és Lechner korában, TERC Kiadó, Budapest, Hungary, pp. 318-351. (in Hungarian)

Bánrévy, Gy. (1933) "A budavári katonai szertár (Zeughaus) 1725-1901" (The military equipment store in Buda (Zeughaus) 1725-1901), Tanulmányok Budapest Múltjából, 2, pp. 104-140. (in Hungarian)

Bede-Fazekas, J. (2016) "Id. Schömer Ferenc neogótikus építészete" (NeoGothic architecture of Ferenc Schömer Sr.), Műemlékvédelem, 60(1-2), pp. 41-52. (in Hungarian)

Fábián, G. (1922) "Velencei dr. Hauszmann Alajos" (Dr. Alajos Hauszmann from Venice), Építő Ipar - Építő művészet, 46(23-24), p. 94. (in Hungarian)

Gábor, E. (1996) "Schickedanz Albert építőmüvész" (Albert Schickedanz architect), In: Schickedanz Albert (1846-1915) - Ezredévi emlékművek múltnak és jövőnek, Szépművészeti Múzeum, Budapest, Hungary, pp. 13-64. (in Hungarian)

Gábor, E. (2000) "Azállandó Országház tervpályázata 1883-ban" (Planning competition of the Parliament building in 1883), In: Az ország háza: Buda-pesti országháza tervek 1784-1884, Szépmúvészeti Múzeum, Budapest, Hungary, pp. 138-170. (in Hungarian)

Gy. Balogh, Á. (2013) "A lágymányosi telek története. A campus építésének története." (The history of the site in Lágymányos. Campus construction history.), In: Armuth, M., Lőrinczi, Z. (eds.) Müegyetem - a történeti campus / The Historic Campus: A Budapesti Műszaki és Gazdaságtudományi Egyetem történeti campusa / The Historic Campus of the Budapest University of Technology and Economics, Budapesti Müszaki és Gazdaságtudományi Egyetem, 6Bt, Budapest, Hungary, pp. 40-53. (in two languages: in Hungarian and in English)

Gyetvainé Balogh, Á., Juhász, A., Kelecsényi, K. Z., Székely, M. (2018) "Földművelésügyi Minisztérium. Építéstörténeti Tudományos Dokumentáció" (Palace of the Ministry of Agriculture. Scientific documentation of the construction history), Manuscript (authors collection, It is an unpublished documentation about protected buildings, ordered by the 68/2018 (IV.09.) goverment regulation. It is used during the process of reconstruction planning and authorisation.), Budapest, Hungary. (in Hungarian)

Gyetvainé Balogh, Á., Kelecsényi, K. Z. (2018) "Did a Steindl School exist? The members of the design and technical management team of the Parliament in Budapest", Architektúra \& Urbanizmus, 52(1-2), pp. 98-113.

Hadik, A. (1984) "Foerk Ernő, az építész - Foerk Ernő (1868-1934) építész emlékkiállítása" (Ernő Foerk architect - exhibition of Ernő Foerk (1868-1934) architect), OMF Magyar Építészeti Múzeuma, Budapest, Hungary. (in Hungarian) about the architectural practice of the last third of the $19^{\text {th }}$ century, allowing us to more fully outline a conventional architectural career in the era of Historicism.

Hauszmann, A.(1892a)"A budapesti királyi palota-építés művezetőségének ideiglenes iroda-épülete" (Temporary building of the office of the foremanship of the Royal Palace of Budapest), Építő Ipar, 16(20), p. 134 (fig.: Ground floor), p. 135 (text); 16(22), p. 149 (fig.: Under ground floor); 16(23), p. 157 (fig.: Attic level); graphic suppl.: 10. (west façade); 11. (south façade); 12. (north façade).

Hauszmann, A. (1892b) "A "New-York" életbiztosító-társulat budapesti palotája" (Palace of the "New York" Life Insurance Company in Budapest), Magyar Mérnök- és Építész-Egylet Közlönye, 26(10), pp. 321-325. (in Hungarian)

Hauszmann, A. (1896) "A fiumei kormányzó palotája" (Representation of the building of the Governor's Palace in Fiume), Magyar Mérnökés Építész-Egylet Közlönye, 30(5), pp. 177-188. (in Hungarian)

Hauszmann A. (1897) "A budapesti igazságügyi palota" (Palace of Justice in Budapest), Magyar Mérnök- és Építész Egylet Közlönye, 31(2), pp. 56-68. (in Hungarian)

Hauszmann, A. (1995) "Hauszmann Alajos (1847-1926) önéletrajza" (Autobiography of Alajos Hauszmann), In: Hajdú, V., Prakfalvi, E. (eds.) Lapis Angularis: Források a Magyar Építészeti Múzeum gyűjteményéből, OMvH Magyar Építészeti Múzeum, Budapest, Hungary. pp. 12-72. (in Hungarian)

Hauszmann, A. (1997) "Hauszmann Alajos Naplója: építész a századfordulón", (Diary of Alajos Hauszmann: architect at the turn of the century) (compiled by Seidl, A.), Gondolat Kiadó, Budapest, Hungary. (in Hungarian)

Havas, Gy. (2017) "Schweiger Gyula építész életműve" (Oeuvre of Gyula Schweiger architect), MA Thesis, Pázmány Péter Catholic University, Hungary. (in Hungarian)

Kelecsényi, K. Z., Gyetvainé Balogh, Á. (2019) "Egy középület gyors esztétikai és funkcionális avulása: A Földmüvelésügyi Minisztérium palotájának első két évtizede" (Rapid aesthetic and functional obsolescence of an administrative building: First two decades of the Palace of the Ministry of Agriculture), Építés Építészettudomány, 47(1-2), pp. 83-101. (in Hungarian) https://doi.org/10.1556/096.2018.010

Kemény, M. (2010) "A Szent István-bazilika - Építészet, város, történelem" (St. Stephen's Basilica - Architecture, city, history), TERC Kiadó, Budapest, Hungary. (in Hungarian)

Keserü, K. (2007) "Toroczkai Wigand Ede" (Ede Toroczkai Wigand), Holnap Kiadó, Budapest, Hungary. (in Hungarian)

Komor, M. (1930) "Korb Flóris 70. születésnapjára" (On the 70 ${ }^{\text {th }}$ anniversary of Flóris Korb), Magyar Mérnök- és Építész-Egylet Közlönye, 44(23-24), pp. 217-219. (in Hungarian)

L-r. (1905) "A budapesti Szent-István-templom [III.]", (St. Stephen's Church in Budapest [III.]) Építő Ipar, 29(48), pp. 391-394.

N. N. (1895) "Az erzsébetvárosi templom alapkövének letétele" (The foundation stone of the church in Erzsébetváros), Pesti Hírlap, 17(289), pp. 2-3. (in Hungarian) 
N. N. (1915) "Halálozás" (Deaths), Magyar Mérnök- és Építész-Egylet Közlönye, 49(33), p. 188. (in Hungarian)

N. N. (1891) "Ybl emlékezete és művei" (Memory and works of Ybl), Vasárnapi Ujság, 38(5), p. 76. (in Hungarian)

Pálinkás, Sz. (2015) "Kármán Géza Aladár (1871-1939) és erényi Ullmann Gyula (1872-1926): A bécsi szecesszió legkiválóbb hazai képviselői" (Géza Aladár Kármán (1871-1939) and Gyula Ullmann from Erény (1872-1926): The most outstanding Hungarian representatives of the Viennese Secession), In: Rozsnyai, J. (ed.) Építőművészek Ybl és Lechner korában, TERC Kiadó, Budapest, Hungary, pp. 352-385. (in Hungarian)

Rostás, P. (2001) "Egy helyiség helye: A Budavári Palota Hunyadi Mátyás-termének története" (Space of a room: The history of the Matthias Hunyadi Chamber of the Buda Castle), Tanulmányok Budapest Múltjából, 29, pp. 487-530. (in Hungarian)

\section{Archival sources}

BFL - Budapest Főváros Levéltára, (Budapest City Archives)

- XI.814. Havel Lipót Építési Cég iratai (Documents of Havel, Lipót, master builder), 58. box.

- XV.17.b.312. Építő Bizottmány tervei (Plans of the Building Commission), 919/1873.

- XV.17.d.329. Építési Ügyosztályok Tervtára (Plan Collection of the Building Departments), hrsz.: 24894, 2. folio - 40330/1884-III. (1884. 08. 08.).

- XV.17.d.329. hrsz.: 24894, 1-3. folio (1884) - 29664/1885-III (17. 06. 1885.).

- XV.17d.329. Építési Ügyosztályok Tervtára (Plan Collection of the Building Departments), hrsz.: 5534. (1906).

- XV.17.f.331.b Ybl Miklós hagyatéka, tervek (Plans from Miklós Ybl's inheritance) 150-24/1. Engineering plan, 1892.

- XV.19.d.1. Klösz György digitális felvételek (Digitalised photos of György Klösz) 07.195.

- XV.19.d.1. Klösz György digitális felvételek (Digitalised photos of György Klösz) 08.092.

- XV.19.d.1. Klösz György digitális felvételek (Digitalised photos of György Klösz) 08.093.

BMEL - Budapesti Műszaki és Gazdaságtudományi Egyetem Levéltára (Archive of the Budapest University of Technology and Economics) - without inv. no.: K-épület építési naplója (Diary about the construction of the K building) 1906-1909.

FSZEK - Fővárosi Szabó Ervin Könyvtár - Budapest Gyüjtemény (Metropolitan Ervin Szabó Library - Budapest Collection) - 020595 inv. no.: Basilika Budapest, Strengel \& Co., Dresden, 1896.

MÉM-MDK - Magyar Építészeti Múzeum és Müemléki Dokumentációs Központ (Hungarian Museum of Architecture and Monument Documentary Centre)

- without inv. no.: Károly Divald Jr.: Steindl Imre mütermében az Országház építői körében (Imre Steindl in his atelier with the builders of the Parliament) (1896).

MNL OL - Magyar Nemzeti Levéltár Országos Levéltára, (National Archives of Hungary)

- K-178. 1120 f. 309-310. (767/1888/eln.).

- T6 No. 8/13. "Budapesti Unitárius Egyház-község templom és bérház épülete", (Budapest Unitarian Church and Tenement House) (1890)
Sándy, Gy. (2005) "Hogyan lettem és hogyan voltam én templom-építö, -tervező és mủvezető építész?" (How did I become and how I was a church builder, designer and foreman architect?), In: Fehérvári, Z., Hadik, A., Prakfalvi, E., Zászkaliczy, Z. (eds.) Lapis Angularis VI.: Források a Magyar Építészeti Múzeum gyűjteményéből, Magyar Építészeti Múzeum, Budapest, Hungary. (in Hungarian)

Sárosi, B. (1902) "A királyi palota" (The Royal Palace), Magyar Üveg- és Agyagipar, 2(6), pp. 6-7. (in Hungarian)

Sisa, J. (2004) "Az Országház: épület és műalkotás" (The Parliament: building and work of art), Ars Hungarica, 32(2), pp. 323-340. (in Hungarian)

Zámborszky, I. (1937) "A magyar országház" (Hungarian Parliament Building), Atheneum, Budapest, Hungary. (in Hungarian)

OBH - Országos Bírósági Hivatal, (National Judicial Bureau)

- Az Igazságügyi Palota építkezése - szerződések (Construction of the Palace of Justice - contracts).

- 44. Róna, József (23. January 1894.).

- 46. Paolo Triscornia di Ferdinando (27. October 1894.).

- 47. Strobl, Alajos (27. October 1894.).

- 34. Magaziner and Weinberger (2. March 1896.).

OH: ÉT - Országgyülés Hivatala; Építészeti Tanácsülési jegyzőkönyvek (Office of the National Assembly; Protocols of the Architectural Council's meetings) - I. session (11. 10. 1884.), I/H.

OH: SZ-E - Országgyülés Hivatala; Országházépítés: Eredeti szerződések, (Office of the National Assembly; Construction of the Parliament building: original contracts)

- 45. (12. 07. 1893.) Contract of Sommer, Ignác.

- 55. (16. 11. 1893.). Contract of Lipót Havel.

OH: VB-JK - Országgyülés Hivatala; Országházépítés: Végrehajtó bizottsági ülések jegyzőkönyvei, (Office of the National Assembly; Construction of the Parliament building: Protocols of the sessions of the Executive Committee)

- XXII. session (28. 11. 1887.), X.

- XLVIII. session (04. 07. 1893.), VI.

- LXVI. session (22. 10. 1896.), IV.

- LXXI. session (02. 07. 1897.), XIII.

OH: VB - Országgyülés Hivatala; Országházépítés: Végrehajtó bizottság iratai, (Office of the National Assembly; Construction of the Parliament building: Documents of the Executive Committee) - 1884-7, 1884-11, 1884-12, 1884-37, 1884-45.

- 1885-29, 1885-36, 1885-49, 1885-56, 1885-58, 1885-69, 1885-73, 1885-123, 1885-126, 29792/1885-III. (09. 07. 1885.), 1885-204.

$-33 / 1887$.

- 321/1893, 334/1893, 374/1893, 435/1893, 476/1893.

$-1895-464$.

$-1898-461$.

$-345 / 1900,394 / 1900$. 